\title{
The Effect of Application Rumah Gadang Puzzle Games on Improving Students' Numeral Ability at TK Permata Hati Sungai Tarab Tanah Datar
}

\author{
Aini Hijriani \\ Early Childhood Education Department, Padang State University, Padang, Indonesia, ainihijriani20@ gmail.com
}

\begin{abstract}
This research originated from the reality in Permata Hati Kindergarten Sungai Tarab that learning to recognize student's numerals is still slow and still needs improvement, due to the use of conventional media that does not give rise to Student's learning spirit. Therefore, researchers use the Rumah Gadang puzzle game in order to help improve the ability to recognize the numerals of Students so that students are more quickly remembered about the learning being taught. The purpose of this research was to find out whether the Rumah Gadang puzzle game can affect the ability to recognize of students numerals in the class B1 Permata Hati Kindergarten Sungai Tarab. This research uses a quantitative approach in the form of Quasy Experiment. The population of this research was the students of B1 Permata Hati Kindergarten Sungai Tarab, and with simple random sampling techniques, namely groups B1 and B2, each of which amounted to 12 children. This study uses research instruments with the ability to recognize the student's numerals. Data collection techniques used observation sheets and then the data was processed by a difference test (t-test). Based on data analysis, the average test results of the experimental class were 19.55, while in the control class it was 14.83 . The results showed that the students in the experimental class who used puzzle house games had higher average values compared to students in the control class with conventional media. Based on the calculation of the t-test obtained t count greater than $\mathrm{t}$ table, which is 3.34 greater than 1.71 , and this indicates that there are differences between the two classes. Thus it can be concluded that the Rumah Gadang puzzle game affects the ability to recognize the numeral of early childhood at Permata Hati Kindergarten Sungai Tarab, the first semester in 2018/2019 academic year.
\end{abstract}

Keywords: Rumah Gadang Puzzle Game, Numeral ability

\section{INTRODUCTION}

Early Childhood Education in UU No 20 of 2003 is an effort to develop children directed at birth from the age of six years through educational stimulation to help grow and develop physically and spiritually so that they have readiness in entering further education. In the limits given by the National Association for the Education of Young Children (NAYC) it is said that early childhood is a child from birth to eight years of age (Ismat Khasanah, 201: 3). Next Bredekp \& Cnnnle in Suryana (2014: 66) states that early childhood education serves the education of children in the age range of birth to eight years of age. Early childhood education provides stimulation for the development of six aspects of development that exist in children which are summarized in early childhood learning.

It can be understood that early childhood education is children from birth to the age of eight years ( $0-8$ years) who are experiencing a process of growing and developing well in terms of cognitive, afektive and psychomotor. Early childhood as education held before the level of basic education. Therefore the implementation of early childhood educating must pay attention to the principle of learning and in accordance with the stages of child development.

The principle of early childhood learning is "learning through play", with play expected to not only inflate cognitive abilities, but also physiology, social emotional, language, and the ability to understand values religion and morals. Playing, or playing as an activity related to the whole child, is not only partially, but through play (when the child is playing) the child will be encouraged to practice his skills that direct children's cognitive development, development of children's language, psychomotor development, and physical development. The hermain experience will encourage children to be more 
creative. Starting from emotional development, then leads to socializing creativity.

Hurlock in Putri Admi (2013: 4) say that playing is a serious activity and is a main activity in childhood. Playing is also a need that already exists with itself. A teacher must have a specific strategy to convey learning to children and one of them is in the introduction of the concept of numbers in children. As explained above, one of the principles of early childhood learning is learning while playing, it can be understood that the introduction of the concept of numbers in children can be done by educators through games. One aspect that is of concern to the teacher is cognitive development. Cognitive development of cognitive children includes the ability to have curious behavior, be creative, get to know the surrounding objects, get to know the social environment and the natural environment (Ali Nugraha.dkk, 2015: 33)

The concept of numbers is a very important mathematical concept mastered by children, which consists of counting numbers, sorting words, entering numbers, and comparing. According to Jean Piaget in Dadan Suryana (2016: 83) suggests that cognitive development of each child through four stages, namely the sensory motor stage (0-2 years), preoperational (2-6 years), concrete operational 6-1 years), and formal operational 1-12 years). At the preoperational stage, children's thinking activities do not yet have a variety of organized systems, but children are able to understand the reality of the environment by using signs and symbols.

Gradually this stage of the child is able to think in one direction. In this way the child is also able to understand the concept of numbers and symbols. In mathematics learning, the concept of numbers can be expressed in a symbol that is a symbol of numbers. As has been stated that the concept of numbers is abstract, it tends to be difficult to understand by the kind of Kindergarten where the thoughts of Kindergarten children are based on concrete studies. To be able to develop the concept of numbers in Kindergarten children are not carried out in a short period of time, which must be done in stages over a long period of time, and concrete media is needed to help the process of learning to recognize losses. Furthermore, mode I education for early childhood must be adapted to the period of their development which is still dominated by games as a medium of knowledge transfer One model that is suitable to be used in the introduction of the concept of numbers is through the rumah gadang puzzle game

The media that use in the introduction of the concept of numbers in children is the media image that is in the form of a picture of the Rumah Gadang, which later in innovation became a puzzle game. The reason the researchers made this game was because parents were concerned about cultural preservation that had been inherited from generation to generation while today's children were more interested in playing with advanced technologies such as playstation, online games, tablets and gajet. So that children are not familiar with the surrounding culture and one of them is that children are not familiar with the traditional forms of Minangkabau. Therefore, the author tries to compile a model of introducing the concept of numbers through image media based on Minangkabau culture.

Based on the observations of researchers in the learning activities taking place at Permata Hati Kindergarten, in group B1 (5-6 years) there were 12 people. Researchers found that the ability to recognize the number of children is still very low. When learning to recognize numbers, researchers found results, namely from 12 children, there were only 6 children who already understood in mentioning numbers 1-10 but the child was still confused when asked to show numbers and match the shape of the loss. Besides that, there are only 7 children who write numbers 110 and only 6 children can recount 1 10 numbers in sequence.

The method used in the development numeral ability in the Kindergarten is also less varied. In the introduction of numbers teachers only use the lecture method and sing. As long as in teaching basic mathematical concepts, the teacher only asks the child to read together to mention the number of the child only given a worksheet containing numbers 1-10 then the child is assigned to write and make healthy one by one number. Starting from the background and scope of the money above, the purpose of this paper is to find out the effect of puzzel house games on the ability to recognize numbers at Permata Hati Kindergarten

\section{THEORY}

\section{The essence of early childhood}

According to the Early Childhood Directorate based on UU no. 20 of 2003 Article 28 concerning the National Education System in Indonesia, early childhood is a group of people aged 0-6 years (Tuti Andriani, 2012: 3). The National Association for the Education of Young Children NAEYC) said that early childhood is a child from birth to eight years old (Ismatul Khasanah, 2011: 3). This is different from the opinion of Suryana that early childhood is a period of humanity that has a uniqueness that needs to be considered by adults, unique early childhood in their potential and service must be very important so that every potential can become the foundation in following the next stage of development (Dadan Suryana , 2013: 7).

Based on this opinion, it can be concluded that early Indonesian children are children who have been born to eight years old (0-8 years) who are undergoing a process of recovery and recovery both in terms of cognitive, affective and psychomotor. Early childhood as education held before the level of basic education, therefore the implementation of early childhood learned has paid attention to the principle of learning and in accordance with the stages of child development.

2. Introduction of Numbers for Early Childhood Early Childhood Mathematics

People since early childhood have started counting, at the age of 2 years have started to be biased to count, such as counting before blowing out birthday candles, or through games and singing 
(Susan Sperry, 2009: 89). This means that Mathematics cannot be separated from life, because mathematics is a human way to solve problems in life Mathematics is one indicator of early childhood intellectual development, as Piaget's theory states that Cognitive development includes: classifying Object, Seriating, Dealing with numbers, understanding concept of time and space, distinguishing between reality ang fantasy, and understanding the principle of conservation Diane E Papalia, 1990: 419) Dapa is understood that mathematics is part of human cognitive development including the ability to group objects to sort objects according to size, count and so on.

\section{Definition of numbers in children}

After early Numbers are a term for expressing the number or number of things. Numbers include zero numbers, negative numbers, positive numbers, rational numbers, irrational numbers, computational numbers. Galistell in Susan stated that (2009: 91):

"Counting and number relationship develop slowly over the first seven years, preschoolers count in a mechanical or rore fashion. This Ability has three prerequisite principles or rules: the stable order rule, the one-to-one rule, and the abstraction rule"

It is understandable that the development of children in traditional concepts is slow at the age of 7 years and there are three principles in the concept of calculating numbers, Rational number for one object, and count more than one object.This means that the development of the concept of numbers is related to language that is, counting and counting

According Depdiknas (in Hayati 2007 8) explains that the numbers that children begin to learn are numbers for calculating quantities. According to Triharso (2013: 49) numbers are one of the most important mathematical concepts learned by children. numbers include developing a sense of quantity and understanding one-to-one conformity. When sensitivity to children's numbers develops, they become increasingly interested in calculating counting. Counting is the basis for early work of children with numbers. . According to Gelman Ni Made (2018: 5) numbers to train number sense to children can be done since they were young. They have known numbers even though they have not understood the calculation Numbers as a form of symbolic thinking make it possible for children to learn through simb symbols. Supporting this according to Musfiroh (2012: 24) suggests that numbers aim to stimulate numerical abilities, namely symbols of numbers, concepts of numbers, addition, subtraction.

The concept of numbers or numbers should be introduced from an early age because the concept of numbers is the child's basic capital in menen lmu $\mathrm{m}$ mathematics. According to the Depdiknas (2007: 10) the ability to recognize numbers for children aged 5 to 6 years (group B), namely the child can name numbers up to 10 in sequence, show numbers 1 through 10 randomly, mention numbers up to 10 randomly, show the number of objects in order, count while pointing objects in order, look for numbers according to the number objects, showing a collection of objects whose numbers are the same, not the same, more and less and mentioning the objects they have just seen.

Based on the above explanations, it can be concluded that the ability to recognize numbers in this research is the ability that is expected to be possessed by children in recognizing the important elements contained in numbers such as names, sequences, symbols and numbers, including mentioning numbers 1 through 10 in sequence, pointing numbers I to 10 at random, showing the number of objects in sequence, counting while pointing objects sequence, look for numbers according to the number of objects and show a collection of objects whose numbers are the same, not the same, more and less.

\section{Characteristics of Learning Knowing Numbers for}

\section{Early Childhood}

In delivering learning material material to recognize numbers in early childhood cannot be done in a hurry, but gradually thirsty. Sujiono (20 10.32), the characteristics of recognizing the numbers of early childhood are:

a. Numerating or naming numbers

Numerals are used by children to show knowledge of the names of numbers and number systems. One of the most effective ways to develop the ability to recognize numbers to children is to create a habit that is related to numbers

b. Counting by pointing objects (recognizing the concept of numbers with objects)

Teachers and parents can train children to say by pointing to objects around the child both at home and at school. Objects that are at home and school for example many chairs, tables and so on.

c. Make a sequence of numbers with objects

d. Connecting or pairing symbols with objects

Thus it can be concluded that when it comes to providing learning to recognize numbers in early childhood it cannot be done in origin or in a hurry, but must be done in stages starting from the easiest to the tersul, namely starting from recognizing the concept of numbers, connecting the concept to the number symbol and introducing the symbol number. Through the right stages, it is expected that children can recognize numbers easily.

\section{Puzzle Rumah Gadang}

Rumah Gadang is a traditional Minangkabau house. Rumah Gadang is one of the traditional houses in Indonesia located in West Sumatra. Rumah Gadang is an history for the Minangkabau people. This house is also called by another name by the local community by name Rumah bagonjong or there are also healthy houses with the name rumah baanjuang. Rumah 
gadang discussed here is the Gadang Palace of Pagaruyung House or better known as Istano Pagaryug Istano Basa l'agaruyung is located in Pagaruyung of Tanah Datar District, West Sumatra Istano Basa l'agaruyung is the name of the residence of the Minangkabau royal family which at the same time became the Center of the Minangkabau Kingdom in its time.

The construction of the building is different from the house where ordinary people live. Pagaruyung palace consists of 3 floors, 72 pillars and gnong. The building architecture of the Pagaruyung Palace shows special characteristics compared to the Rumah gadang buildings in Minangkabau. The peculiarities possessed by this building are implied by the physical form of the building which is complemented by engraving the Minangkabau philosophy and culture. Paguruyung palace is equipped with dengun surau, tabuah, rangkianag has specific meanings (Chandra Okta Fiandi, 2012: 15

According to Hasanuddin 2012: 30) Pagaruyung palace that we usually visit today is a replica of the palace burned down by the Dutch in 1804 . The fire disaster seems very close to this palace. after 1804 fires also devastated the palace in 1966 and 2007. Each element of the rumah gadang has its own symbolic meaning. The Rumah Gadang section includes:

\section{a. Gonjong/ Roof}

The shape of the rumah gadang roof which is like a buffalo horn is often associated with the story of Tambo Alam Minangkabau. The best story about the victory of the $\mathrm{Mg}$ in the event of an ape against the Javanese. The roof of his house is made of palm fiber. The curved and pointed roof shape upward is stretched. Because the roof forms a gonjong, the rumah gadang is also called the rumah bagonjong,

b. Room

This loose space is a room that is divided into lanjar and rung and is marked by a pole. The rumah gadang pillar flies from face to back or from left to right, the pillar that runs from front to back marks the lanjar, while the pole from left to right marks space. So, what is called space is the room from front to back. lanjar works from left to right. Comparison of space and space is one third for sleeping space and two thirds for public space, this means that public interests take precedence over personal interests. The number of rooms usually consists of an odd number between three and eleven, according to the number of female occupants in the house. According to adat, a rumah gadang must have a minimum of five rooms, and the ideal number is Nine.

c. Under the Floor

As a large house, inside the rumah gadang there are parts that have special functions. The lan part of the rumah gadang is the bottom of the floor.
This section is called a cage (under) from the rumah gadang. Sometimes (under) the rumah gadang is high enough at least 2 meters and wide. In the Minahasa philosophy, it functions as a storage place for the needs of home residents, such as firewood, agricultural tools or used as a place for women to weave and store other objects.

It is understandable that every part of the rumah gadang has its own philosophy, as a whole, as a ship which means that this rumah gadang is a refuge in navigating a life ship. The hermetic staircase of the process of life, the roof or jolt resembling a buffalo horn illustrates the important history of the Minangkabau and the broader distribution of the general space than specifically meaning the public interest more than the personal interests of the Houses.

\section{Rumah gadang puzzle game}

Puzzle and make children feel happy with learning. For learning to be more interesting, educators need to make media in accordance with the learning theme..Media that can develop aspects of a child's development. The term media in the field of learning is also called learning media. In the process of learning, tools or media not only can facilitate the communication process but can stimulate students to respond well to all messages conveyed.

The word puzzle comes from English which means puzzles or unloading pairs, puzzle is a medium of learning by playing unloading (Pascalian Hadi, 2016: 7):

a. The function of the puzzle

The function of the puzzle game is :

1) Train concentration, thoroughness and patience

2) Train eye and hand coordination

3) Train logic

4) Strengthen memory

5) Introduce the child to a relationship

6) By selecting images can train mathematical thinking of various

b. Types of puzzle

kinds of children kinds of puzzles (Pascalian Hadi. 2016: 9)

1) Construction puzzles

2) Trunk puzzles

3) Puzze floors

4) Puzzle numbers

It can be understood that the media puzzle is a tool in learning activities so that learning objectives can be achieved. The media can be played by children, so that children will get direct experience through the scientific process in the form of communicating, asking questions, gathering information and communicating the experiences of children. Media made by educators in improving the ability to recognize numbers is a game of Rumah gadang Puzzle. As explained above, the puzzle is a medium that is played by unpacking or arranging 
puzzle pieces with other pieces so that the whole picture and the building of the whole space will be formed.

\section{METHODS}

Type of research

This type of research was a quasi-experimental experiment. According to (Arikunto 2005: 209) quasiexperimental research is experimental research that does not succeed in attempting or realizing the conditions expected in pure experimental research (conditions) that are conditions that cannot be tightly controlled so as to influence the final learning outcomes of students such as economic conditions, psychology, location, etc. Frankel in A. Muri Yusuf (2014: 77) states that the uniqueness of this study is (1) the type of research that gives opportunity to researchers to directly influence research variables and (2) research that can test hypotheses about causal relations.

The purpose of Quasi-experiment is to obtain information which is a thought for information that can be obtained by actual experiments in circumstances that do not allow to control and manipulate all relevant variables. The implementation of quasi-experimental researchers is the same as the implementation of pure experimental research, which can be done by giving treatment to the experimental class by using pocket board media and ordinary (conventional) media in the control class.

Quashi experiment with a type of nonequivalent control group design that aims to find out the effect of independent variables on the dependent variable after the bowling game is used puzlle rumah gadang

\begin{tabular}{|c|c|c|}
\hline \multicolumn{2}{|c|}{ Table 1. Research Design } \\
\hline Pre-test & Treatment & Post-test \\
\hline $\mathrm{O}_{1}$ & $\mathrm{X}$ & $\mathrm{O}_{2}$ \\
\hline $\mathrm{O}_{3}$ & - & $\mathrm{O}_{4}$ \\
\hline Note: & \\
$\mathrm{O}_{1}$ & : Pre-test experiment class \\
$\mathrm{O}_{3}$ & : Pre-test control class \\
$\mathrm{X}$ & : action with puzzle rumah gadang \\
$\mathrm{O}_{2}$ & : Post-test experiment class \\
$\mathrm{O}_{4}$ & : Post-test control class
\end{tabular}

It means that researchers conduct research into a group of samples, where the sample has been divided into two groups, namely as the experimental group and the control group. But before the experimental group was given treatment $(\mathrm{X})$, then the two groups were first given a pre-test (O) to see the condition of each group, after reaimei $(\mathrm{X})$ was given to the experimental group and then given a re-test $(\mathrm{O} 2$ and the results are distinguished from the results of the first test In general, the steps to carry out experimental research are:

1. Pretest, namely giving a test in the form of questions or statements to measure the initial condition of the ability to recognize the number of children before being given treatment $(\mathrm{O})$ to the experimental group and to the control group .
2. Treatment, giving treatment to the ability to recognize the number of children using bowling games.

3. Giving a posttest after the treatment was astonished, then conducting a test, both to the experimental group and the control group

\section{Research Place and Time}

1. The Research Place of this Research conducted at Permata Hati Sungaitarab Kindergarten at Tanah Datar

2. Research Time

The implementation of the study was conducted in the first semester, 20182019 school year

\section{Population and Sample}

1. Population

A.Muri Yusuf (2014: 146) stated that the population is the overall unit of analysis in accordance with the desired information, while Sugiyono 2013 8) said that the population is a region of generalization consisting of ohjek / subject that has certain qualities and characteristics determined by the researcher to be studied and then draw conclusions ". The population in this study was all students at Permata Hati TK Tarab River which numbered 24 people.

2. Sample

The sample is part of the number and characteristics possessed by the population. The sampling technique or sampling technique is a way to take smpe. In this case the sampling that the researcher uses is by using Purposive Sampling techniques. According to Sugiyono (2007: 12) Purposive Sampling is a technique of determining samples with certain considerations so that the data obtained is more representative by conducting a research process that is copetent in their field. So it can be said that Purposive sampling is deliberate sampling in accordance with the requirements of the sample required by the researcher.

Based on recommendations from group B educators that more than half of children in Tk Permata Hati Sungai Tarab cannot recognize numbers. Therefore, the authors chose the BI group as the sample in this study which amounted to 12 people. The following which will be sampled in this study at Permata Hati Kindergarten are:

Table 2. Sample of the research in B1 class

\begin{tabular}{|c|c|c|}
\hline No & Kode Anak & Jenis Kelamin \\
\hline 1 & AF & P \\
\hline 2 & ARH & L \\
\hline 3 & DPS & P \\
\hline 4 & FM & L \\
\hline 5 & FA & L \\
\hline 6 & JP & P \\
\hline 7 & FV & L \\
\hline 8 & MR & P \\
\hline 9 & NV & L \\
\hline 10 & PAP & L \\
\hline 11 & ZAM & L \\
\hline 12 & RP & \\
\hline
\end{tabular}


IV. RESULT

Table 3. Recapitulated Pre-Test (first ability) numeral in experiment class and control class

\begin{tabular}{|l|c|c|c|c|c|c|}
\hline Group & $\begin{array}{c}\mathbf{X} \\
\text { bar }\end{array}$ & $\mathbf{N}$ & $\mathbf{S}$ & $\mathbf{S}^{\mathbf{2}}$ & $\mathbf{X}_{\boldsymbol{m a}}$ & $\mathbf{X}_{\boldsymbol{m} \boldsymbol{i n}}$ \\
\hline Experi & 69,1 & 12 & 6,34 & 40, & 80 & 60 \\
ment & 7 & & & 15 & & \\
\hline control & $\begin{array}{c}65,4 \\
2\end{array}$ & 12 & 8,11 & 65, & 75 & 50 \\
& & & 72 & & \\
\hline
\end{tabular}

Form the table know different the experimental class and control class at Permata Hati Kindergarten in Semester I 2018/2019 school year with 12 children. After obtaining the pre-test for the introduction of the number of children, it can be seen that the highest score achieved by the child is 80 and the lowest value is 60 . For the control class the highest value is 75 and the lowest value is 50 .

Data obtained from the experimental class at Permata Hati Kindergarten in Semester I am in the year 2018/2019 with 12 children. After obtaining the post-test introduction of the child's loss, it was seen that the highest score achieved by children was 100 and the lowest value was 75 . For the control class the highest score was 85 and the lowest score was 65 .

To describe conclusions about the data obtained from the post-test introduction Child loss can be done by statistical analysis. Before conducting a hypothesis test, the normality test and the variance homogeneity

Normality test

Normality tests are carried out by liliefors test. The iiefors test was carried out to see whether the sample was distributed normally or not. The steps in conducting liefors tests on sample classes are the same as conducting liliefors tests on population classes.

Tabel 4. Result Nomality test at sample class

\begin{tabular}{|l|c|c|c|c|c|}
\hline Group & $\mathbf{A}$ & $\mathbf{N}$ & $\mathbf{L}_{\mathbf{0}}$ & $\mathbf{L}_{\text {tabel }}$ & $\begin{array}{c}\text { Distribu } \\
\mathbf{s i}\end{array}$ \\
\hline $\begin{array}{l}\text { Experi } \\
\text { ment }\end{array}$ & 0,05 & 1 & 0,22 & 0,24 & $\begin{array}{c}\text { Normal } \\
\text { distributi } \\
\text { ons }\end{array}$ \\
\hline control & 0,05 & 1 & 0,16 & 0,24 & $\begin{array}{l}\text { Normal } \\
\text { distributi } \\
\text { ons }\end{array}$ \\
\hline
\end{tabular}

From the table it appears that in the experimental class Labs are obtained, $\mathrm{L}_{\text {tabel }}=0,242$ with a real level $\alpha=$ 0,05 . If $\mathrm{L}_{0}<\mathrm{L}_{\text {tabel }}$ then the control class is normally distributed

\section{Homogeneity Test}

The homogeneity test is analyzed by the $f$ test. The homogeneity test aims to see whether the two samples have a homogeneous variance or not after the homogeneity test has been done with the $f f$ test according to the steps.

In the table above it can be seen that the $F$ obtained is 1.47 obtained by the value of $F_{\left(1-\frac{\alpha}{2}\right)}\left(n_{1}-1, n_{2}-1\right)$ is $\underline{0.28}$ and the $F_{\left(\frac{\alpha}{2}\right)\left(n_{1}-1, n_{2}-1\right)}$ is $\underline{3.47}$. Therefore
$F_{\left(\frac{\alpha}{2}\right)\left(n_{1}-1, n_{2}-1\right)} \quad$ or $\underline{0.28}<\underline{147}<\underline{3.47}$, then it can be argued that the data sample class has a homogeneous variance

\section{Hypothesis Test}

Based on the normality and homogeneity tests that have been done, it turns out the two classes are distributed:

\begin{tabular}{|l|c|c|c|c|c|}
\hline \multicolumn{1}{|c|}{ Group } & $\mathbf{x}$ bar & $\mathbf{N}$ & $\mathbf{S}$ & $\mathbf{t}_{\text {hitung }}$ & $\mathbf{t}_{\text {tabel }}$ \\
\hline Experiment & 84,58 & 12 & 8,11 & 3,34 & 1,71 \\
\cline { 1 - 3 } control & 67,34 & 12 & 6,69 & & \\
\hline
\end{tabular}

The pair of hypotheses to be tested in this study is Description:

$\mathrm{H}_{0}: \mu_{1}=\mu_{2}$

$\mathrm{H}_{1}: \mu_{1}>\mu_{2}$

$\mathrm{H}_{0}$ : The introduction of numbers using the puzzle rumah gadang game is the same as using conventional media

$\mathrm{H}_{1}$ : the introduction number using the puzzle rumah gadang game is better rather than the introduction of numbers using conventional media.

$\mu_{1}$ : mean of experiment class

$\mu_{2}$ : mean of experiment class

The average results of the introduction of control class child numbers Based on the results of calculations with the t-test the price of $\mathrm{fn}$ is 3.34 while the ahet is 1.71 at the real level a-0.05. Meaning that is 3.341 .71 , then Ho is rejected, accepted Hi. So it can be concluded that the introduction of numbers using the Rumah gadang puzzle game is better than the introduction of numbers using conventional media.

\section{DISCUSSION}

The word puzzle comes from English which means puzzle or unloading install, puzzle is a medium of learning by playing unloading like puzzle puzzle construction, stem puzzle floor puzzle and puzzle number (Pascalian Hadi, 2016: 7). The only puzzle that is made is the type of construction puzzle which is a form of construction and here we need to embed elements of local wisdom, namely the house of gadang puzzle. This Puzlle Rumah gadang is a construction puzzle in the form of traditional Minangkabau tribal houses.

Various aspects that can be developed through the puzzle house design, on aspects of religious and moral values children will know the philosophical meaning of the house gadang in a simple way, such as the meaning of Nine spaces means as a place of refuge and strengthen friendship among members and know the parts of the rumah gadang. In the aspect of socio-emo development, children will be accustomed to collaborating because permanence is played in groups. On the language aspect, children will learn literacy through playing such as recognizing number symbols and mentioning them. Furthermore, on aspects of cognitive development of children will be:

1. Know numbers symbol

2. have curiosity

3. be creative in composing puzzles 
4. can connect one piece to another puzzle piece so that a complete puzzle is formed

5. get to know the dimensions of dimensions

6. get to know the Minnagkabau social culture environment

Data collection was carried out in two sample groups consisting of an experimental group of 12 children and a control group of 13 children. The research data obtained came from Pre-test and Post-iest that used five items of research instruments, with the assessment criteria of each instrument, namely: (1) Berkembang Sangat Baik (BSB) given a score of 4: (2) Berkembnag Sesuai Harapan (BSH) given a score of 3; (3) Mulia bisa (MB) given a score of 2, (4) Belum bisa (BB) to be given a score of 1 .

This study was conducted four treatments, with five meetings, five meetings of the experimental group (B) consisting of one pre-test and then the treatment four times ended with one post-test, the post-test was carried out on the last day of pre -test. At the meeting the number will be examined. In the experimental group (B1) four meetings were held during treatment with the loss on the first day, namely, 2,3,4,5. The second day is $6,7,8,9,10$. The third day of the number is $5,6.7,8.9,10$. At the post-test the numbers are $1,2,3,4,5,6,7,8,9,10$. In the control group (B2) a meeting was held with a number on the first day, namely $1,2.3,4.5$. The second day of the number is $6,7,8,9,10$. The third day of the loss was 5.6,7.8,9,1. When the post-test number is $1,2,3,45,6,7,8,9,10$

Based on the description and analysis of the final test data, it can be seen that the ability to know the analk number of the experimental class is better than the ability to recognize the number of the control class. The ability to recognize numbers by using puzzle games turns out to help children to improve their ability to recognize numbers, although there is little difficulty in managing children when they will play with the game because children are enthusiastic and scramble to play it. But here the child follows the learning spirit with the puzzle game Rumah Gadanng seen when the child is curious about the numbers to be introduced, the child is curious about what games to show, the child eagerly repeats and sorts the numbers taught, mentions the sequence of numbers, pairs of symbols with numbers.

This shows that the introduction of numbers using the pule house game is done well, because with this puzzle house game, the child is guided to focus and pay attention to the educator, because here the educator displays each number that will be introduced. By using this Rumah gadang puzzle game, the child is also active in learning because the child will be asked to advance to the front to arrange a sequence of numbers on the bottle and mention the number in sequence.

\section{CONCLUSION}

Based on the results of the research data analysis that has been done, it can be taken as follows:

1. Based on the results of research conducted at Permata Hati Kindergarten at Tanah Datar, the results of the ability to recognize the loss of children in the experimental class B) were using higher puzzle games than children in the control class (B2) using conventional media (14.83) to experimental class and (19.55) for contr class

2. In the hypothesis test the results of ${ }_{n g}>t_{\text {tabel }}$ atau $3,34>1,71$

3. The ability to recognize the number of children with puzzle games has proven to be effective in increasing the ability to recognize the number of children because it influences the ability to recognize the number of children in Permata Hati Kindergarten. This can be seen from the ability to recognize the number of children increased can be seen in the number or numerical order correctly and correctly, say by pointing objects correctly, making a sequence of numbers with objects correctly connecting or pairing symbols of numbers with objects and with games this puzzle is the child is also enthusiastic in participating in learning.

\section{REFERENCE}

[1] Ali Nugraha.dkk, 2015, Penyusunan Kurikulum Tingkat Satua Pendidikan (KTSP) Pendidikan Anak Usia Dini, Jakarta: Direktorat Pembinaan Pendidikan Anak Usia Dini.

[2] Chandra Okta Fiandi. 2017. Keajaiban Arsitektur Rumah Gadang, Badan Pengembangan dan Pembinaan Bahasa.

[3] A.Muri Yusuf, 2014. Metode Penelitan Kuantitatif, Kualitatif dan Pengembangan, Jakarta: Kencana.

[4] Depdiknas. 2003. Undang-undang RI No.20 tahun 2003 tentang sistem pendidikan nasional. Jakarta: Depdiknas.

[5] Hasanuddin. 2012. Nilai Budaya dan Sosial Rumah Gadang, Sumatera Barat: Program Kegiatan Inventarisasi Perlindungan Karya Budaya Gadang.

[6] Hayati, F. 2016. Peningkatan Kemampuan Mengenal Angka Melalui Permainan Puzzle rumzh gadang Anak Kelompok A Di Paud Kasih Ibu Banda Aceh, eJurnal Penelitian STKIP Bina Bangsa Getsempena .

[7] Ismatul Khasanah. $d k k$,. 2011. Permainan Tradisional Sebagai Media Stimulasi Aspek Perkembangan Anak Usia Dini, - journal.upgris.ac.id.

[8] Maulana Abdullah. 2018. Pola Ruang Dalam Bangunan Rumah Gadang di Kawasan Alam SurambiPagu-SumateraBarat,Sumatera Barat:Tp

[9] Pascalian Hadi Pradana.2016. Pengaruh Permainan Balok Angka Terhadap Kemampuan Mengenal Lambang Bilangan Pada Anak Usia Dini, Jurnal PAUD Tambusai Volume 2 Nomor 2. 
[10] Putri Admi Perdani. 2013.Peningkatan Keterampilan Sosial Anak Melalui Permainan Tradisional PA Perdani - JPUD-Jurnal Pendidikan Usia Dinijournal.unj.ac.id

[11] Sugiyono. 2007. Metode Penelitian Pendidikan Pendekatan Kuantitatif, Kualiatatif Dan $R \& D$. Bandung: Alfabeta.

[12] Suryana, Dadan. 2013. Pendiidkan Anak Usia Dini, pustaka.unp.ac.id.

[13] Suryana, Dadan. 2014. Kurikulum Pendldtkan Anak Usia DinI Berbabasis Perkembangan Anak, Jurnal Pesona Dasar Vol. 1 No. 3.

[14] Suryana. 2016. Stimulasi dan Aspek Perkembangan Anak, Jakarta: Kencana.

[15] Susan Sperry Smith, Early Childhood Mathematics Fourth Edition, America: Pearson Inc.

[15] Tuti Andriani. 2012. Permainan Tradisional Dalam Membentuk Karakter Anak Usia Dini, _Jurnal Vol 9, - ejournal.uin-suska.ac.id.

[16] Triharso, A. 2013. Permainan Kreatif dan Edukatif Untuk Anak Usia Dini. Yogyakarta: Andi Yogyakarta. 